Contents List available at RAZI Publishing Journal CleanWAS

Journal Homepage: http://www.razipublishing.com/journals/journal-cleanwas/ https://doi.org/10.26480/jcleanwas.01.2017.35.38

\title{
INDOOR AIRBORNE BACTERIA AND FUNGI ATDIFFERENT BACKGROUND AREA IN NURSERIES AND DAY CARE CENTRES ENVIRONMENTS
}

Shahidah N. ${ }^{1}$, Hasnah, S. ${ }^{1}$, Shuhaili, S. ${ }^{1}$, Syamzany, A. ${ }^{2}$, Mohd Shukri, M.A. ${ }^{1}$

1Department of Biotechnology, Kulliyyah of Science, International Islamic University Malaysia, Kuantan Campus, Pahang

2Department of Architecture and Environmental Design, International Islamic University Malaysia, Gombak Campus, Kuala Lumpur

*Corresponding authors: cidanazri@gmail.com \& mamshukri@iium.edu.my

This is an open access article distributed under the Creative Commons Attribution License, which permits unrestricted use, distribution, and reproduction in any medium, provided the original work is properly cited

\section{ARTICLEDETAILS}

Article history:

Received 27 September 2016

Accepted 13 December 2016

Available online 10 January 2017

Keywords:

Indoor air quality (IAQ), nursery, day care centre, pathogenic, airborne bacteria and fungi.

\begin{abstract}
Respiratory symptoms among children cases increased dramatically was believe due to poor indoor air quality. Nursery and day care centre (DCC) appear to be the site of exposure and transmission of airborne microorganism between children. This study aims to assess the relation between the colony forming unit level of biological contaminant (bacteria and fungi) between urban and suburban location correlate with indoor air quality (IAQ) parameters. Besides, the other aims for this study were to identify the types of an airborne pathogenic microbial contaminant in the nursery and DCC. The airborne microbial sampling was done by using Surface Air System Indoor air Quality (SAS IAQ), which taken at the end of June until early August 2015. This study presents the diversity of indoor airborne bacteria and fungi in the nursery and DCC demonstrated in relation to occupancy, location, and ventilation system. Correlation between bacteria and fungi counts and the other IAQ parameters (temperature, $\mathrm{RH}_{\text {, }}$ $\mathrm{CO} 2$, and $\mathrm{CO}$ ) was unable to be studied due to instruments limitation. Counts of airborne bacteria and fungi were measured as colony forming units (CFU) grown on agar plates. CFU counts were compared by sampling sessions and sampling locations (babies room, a kindergarten room, and control room). Fluctuations in bacteria and fungi counts in such conditions were observed. Three groups of culturable bacteria were identified: Grampositive cocci, Gram-positive bacilli, and Gram-negative bacteria while five genera of fungi successfully identified were Aspergillus, Penicillium, Rhizopus, MucorandChrysonilia. Certain bacteria isolated from this study were identified at a species level by $16 \mathrm{~s}$ rRNA amplification including S. haemolyticus, A. baumannii, P. stutzeri, M. osloensis, M. luteus, B. subtilis, Rothia spp., and Roseomonasspp. Overall findings suggest that IAQ level in investigated sites was at poor level due to high bacteria and fungi concentrations with isolation of some opportunistic pathogenic microorganism. This pathogenic microorganism will cause adverse health reaction especially to young children. This study will provide a baseline of hygienic indoor air quality in nursery and day care centre.
\end{abstract}

\section{INTRODUCTION}

By the end of the 20th century, it is estimated that over $75 \%$ of women who have young children will be in the labor force [24]. Due to this, the demand for nursery and daycare services has substantially increased. But, nearly 1 million of children under 5 years die every year due to exposure from indoor air pollutant [32]. Nevertheless, up until now there is no establishment of standard and guideline for the level of indoor air pollution exposure at child care institution. [21]

This indicates that there is less concern in term of indoor air quality in child cares institution even though this is the most susceptible group to get diseases [31]. Children have a high vulnerability to any kind of diseases due to their premature development of their immune system, lungs and another organ. Generally, the nursery is a specific place where babies are cared for. Meanwhile, a day care center is defined as any institution design for the purpose of providing care or maintenance for children less than six years of age. This group of young children's is broadly divided into two main groups, which is the $0-1$ years old and the 2-4 years old [5].

In general, the microbial contaminant will attach to the particulate matter and will be travel through the air. High humidity with low temperature encourages biological contaminants by the growth of mildew and other fungi on the building fabric and furnishings [12]. In Malaysia, the studies on air quality have been conducted but still lack [1] and mostly only focus on a certain base like haze episodes, vehicular emission, and industrialization processes [1]. For IAQ, related studies that were only started in the past few years and the resources are still limited with no specific national guidelines available for indoors. Therefore, the Industrial Code of Practice (ICOP) 2010 established by DOSH was used as a standard in this study.

Taking this into consideration, an assessment of IAQ and its relation to indoor airborne pathogenic bacteria in nursery and day care environment were conducted. The goal of this research is to assess the status of indoor air quality (IAQ) and the diversity of airborne pathogenic bacteria in selected nursery and day care institutions in Kuantan. This study also aims to envisage the correlation of these finding with the level of occupancy, location and building characteristics.

\section{$2.1 \quad$ EXPERIMENTAL}

\section{$2.2 \quad$ Study sites}

2.1.1 Day care center \#1 (ACK): Representing urban location

ACK is representing an urban location where the distance to the main road was near which less than 100meters. This DCC provides service to babies and toddler which meet the requirement of this study. It has babies room for 0-1 years old and kindergarten for 4 years old children. Both rooms have different occupancy and activities that will be correlated with airborne microbial contaminant later. The control room was a non-occupied baby's room that has the similar characteristics.

2.1.2 Day care center \#2 (ACG): Representing sub urban location

The ACG is representing a suburban location where it was far away from the main road and town. The building characteristic and services provided are almost the same as ACK that meets the requirements of this study as well. Sampling was done for three days. Sampling at each location involves three sampling points and four- time intervals. The three points were; baby room, kindergarten classroom and a control room. All the parameters were measured at four sessions depending on the occupants' activities.

\section{$2.2 \quad$ Measurement of airborne pollutants}

\subsubsection{Monitoring and sampling of microbes}

The principle of Surface Air System (SAS) by PBI International started when the air is aspirated at a fixed speed for variable time through a head which has been machined with a series of small holes of a special design. The resulting laminar air flow is directed onto the agar surface of a petri dish containing medium consistent with the microbiological examination to be made. 
Nutrient Agar (NA) for bacteria will be placed in the equipment by unscrewing the top of equipment and will be closed. The SAS IAQ will be set with the flow rate of 1.5 liters of air per minute. The sampler will be started and the position will be maintained at 0.8 to 1.0 meter to represent average breathing zone height for the children. The environmental air will be aspirated fromover the agar surface in the plate and airborne particles were captured on the agar by impaction. Approximately after 60 seconds, the plate will be taken out, closed, sealed, labeled and incubated accordingly at $37^{\circ} \mathrm{C}$ for 24 hours. Then, this method was repeated to PDA plates for fungi. The plate was removed and incubated at $37^{\circ} \mathrm{C}$ for $24 \mathrm{~h}$ for bacteria and at $27 \mathrm{oC}$ for 3 to 4 days for fungi.

\subsubsection{Microbial contaminant count and isolation}

The number of organisms counted on the surface of the "Contact Plate" must first be corrected for the statistical possibility of multiples particles passing through the same hole. The statistical formula is taken from work by J. Maker. Correction Tables for both the $55 \mathrm{~mm}$ standard Contact head, the $84 \mathrm{~mm}$ Maxi-Contact head and the Petri's head. The probable count (Pr) is then used to calculate the Colony Forming Unit (CFU) per cubic meter of air sampled.

For bacteria, isolation of the colonies from previous NA plates will be done by a streaking technique in order to grow pure colony. The plates will be incubated at $30^{\circ} \mathrm{C}$ for 24 hours. The colony morphology (size of the colony, pigmentation, form (shape of the colony), and margin (outer edge of the colony) will be observed and will be recorded accordingly. Isolation of the fungi colonies started by identifies different fungi colonies on PDA plates. Then, the chosen colonies from each plate will undergo pure culture technique to grow pure colony. The plate will be incubated at $27^{\circ} \mathrm{C}$ for another 3-4 days. The colony morphology will be observed and recorded.

\subsubsection{Bacterial identification using PCR}

Identification of bacteria species was done in few steps starting with DNA extraction, determination of DNA quality and quantity using Nanodrop, gel electrophoresis to check the availability of extracted DNA, amplification of 16s ribosomal RNA gene by polymerase chain reaction (PCR), purification of PCR product (clean up), DNA sequencing and sequence analysis by using appropriate bioinformatics tools.

\subsubsection{Fungi identification by morphological study}

The colonies for each pure culture were observed especially the color and texture. To continue with microscopic examination, a fixation step was needed for microscopic analysis. The structure of fungi was observed and recorded. Later, the airborne fungal genera were identified by referring the photographed images to the images captured by Samson [28] in his book.

\section{RESULTS AND DISCUSSION}

Building Characteristic

Table 1: Summarization of building characteristic

\begin{tabular}{|c|c|c|c|c|c|c|c|c|c|}
\hline \multirow[b]{2}{*}{ STATION } & \multirow{2}{*}{$\begin{array}{l}\text { PROXIMUTY } \\
\text { TOMHOR } \\
\text { ROAD }\end{array}$} & \multirow{2}{*}{$\begin{array}{l}\text { TYPE OF } \\
\text { ROOM }\end{array}$} & \multicolumn{7}{|c|}{ BUILDING CHARACTERISTICS } \\
\hline & & & Dimencion & $\begin{array}{c}\text { Ventilation } \\
\text { Type }\end{array}$ & Oceupancy & $\begin{array}{l}\text { Type of } \\
\text { Board }\end{array}$ & Door & Window & $\begin{array}{l}\text { Type of } \\
\text { Fhoor }\end{array}$ \\
\hline \multirow{3}{*}{$\underset{\text { Kunatan }}{\mathbf{A C}}$} & \multirow{3}{*}{ Near } & Boby Room & $2153 \mathrm{~m}^{\prime}$ & Natural & 49 & Cooctete & 2 & $T$ & Cement \\
\hline & & $\begin{array}{l}\text { Kinderganten } \\
\text { (4 years old) }\end{array}$ & $1620 \mathrm{~m}^{\prime}$ & Natural & 23 & Conctite & 2 & $T$ & Thle \\
\hline & & Conitol & $162.0 \mathrm{~m}^{3}$ & Natural & 0 & . & 2 & 1 & Tile \\
\hline \multirow{3}{*}{$\begin{array}{c}\text { AC } \\
\text { Gambang }\end{array}$} & \multirow{3}{*}{$\mathrm{Far}$} & Boby Room & NA & Natural & 25 & - & 4 & 4 & Tile \\
\hline & & $\begin{array}{l}\text { Kinderganten } \\
\text { (4 years old) }\end{array}$ & $\mathrm{NA}$ & Natural & 24 & Cooctrise & 4 & 4 & Tule \\
\hline & & Conitrol & NA & Natural & 0 & - & 2 & 1 & Tile \\
\hline
\end{tabular}

Noke: NA moans Sot drullable

Table 1 shows the building characteristics of sampling sites, ACK, and ACG. From the results, both sites were similar in term of the ventilation system, type of board, and sampling points. However, both sites varied in term of proximity to major roads, and occupancy. Both nurseries and DCCs were equipped with natural ventilation provided through the doors and windows.

Ventilation system has a significant effect on indoor air pollutant levels [36]. The relation between indoor air pollutant levels and ventilations system modes such as natural, hybrid, and or without mechanical revealed that hybrid ventilation system caused a lower level of indoor air pollutants. Nonetheless, in this study, both DCCs have been identified to practice natural ventilation in their premises.

Close proximity to major roads means the nursery and DCC will encounter the higher amount of chemicals release from vehicles. This will influence the IAQ level in these settings due to the release of carbon monoxide (CO). The difference in floor level has an effect on the concentration of particulate matter (PM10) because PM10 normally suspends above the breathing zone level. Occupancy factor, on the other hand, plays a role in determining the indoor levels of CO2 in DCC premises because $\mathrm{CO} 2$ concentration depends on the density of occupants indoors and also outdoor sources.

According to Cionita [7] suggested that for every additional child on every cubic meter in the room, there was an increase in $\mathrm{CO} 2$ concentration by almost $70 \mathrm{ppm}$ [7]. They also highlighted that the average floor space for each child should be at least 3.5 meters. These findings agree with the findings of An, 2006 who disputed that high bacteria counts are associated with high occupancy, poor hygienic conditions of the occupants, and also inadequate ventilation [3].

$$
\text { Total bacterial concentrations according to room }
$$

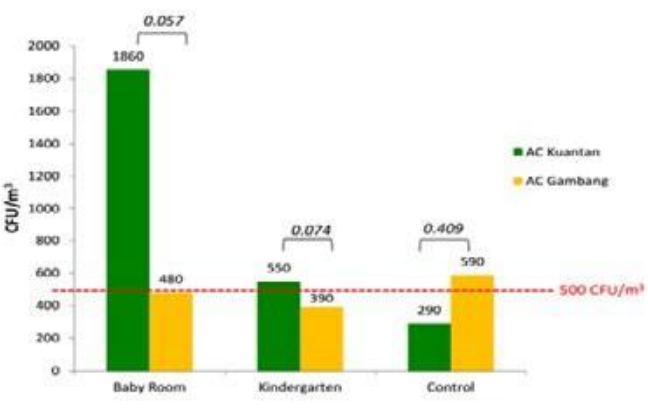

Figure 1: Total bacterial concentration according types of rooms

The recommended threshold level for the biological contaminant (bacteria) in the Malaysian Code of Practice [29] is $500 \mathrm{CFU} / \mathrm{m}^{3}$. According to figure 1 both baby room and kindergarten room of ACK exceed this threshold, it is suggested that the IAQ level was not effective enough in this setting.

Meanwhile, the readings for such rooms in ACG did not exceed the local guideline. In both investigated nurseries and DCCs, the determined level of bacterial air contamination was considerably within the normal range.

However, the concentration of airborne bacteria contaminant in babies' room at ACK was exceeding the standard guideline. This is believed due to the factors occupancy and student's activities in that room. A higher number of total bacteria could be associated with lower temperature and higher percentage of relative humidity. Both of these parameters provided a suitable condition to increase the growth rate of bacteria.

The bacterial counts on nutrient agar (CFU/m3) ranged from $730 \mathrm{CFU} / \mathrm{m} 3$ to $3330 \mathrm{CFU} / \mathrm{m}^{3}$ for both ACG and ACK. The bacterial CFU/ $\mathrm{m}^{3}$ in ACK was significantly higher than that in the ACG in all sessions. The results reveal that the colony counts are highest during session 2 in $\mathrm{ACK}\left(3330 \mathrm{CFU} / \mathrm{m}^{3}\right)$, whereas lowest colony counts were observed during session 3 of ACG $\left(730 \mathrm{CFU} / \mathrm{m}^{3}\right.$ ) when the occupancy is also noted to be the lowest. This pattern of observation might be because of the occupancy factors where is 49 babies in that ACK compare to 25 babies in ACG.

\section{Airborne Bacteria Species}

The bacterial diversity present in a both nurseries and DCCs facilities were studied using the culturing method. Distinct colonies grown one each sampling plate were selected for identification. As shown in figure 2 the Gram-negative bacteria found in this study were Acinetobacter spp., Moraxellaosloensis ,Pseudomonasstutzeri spp. and Roseomonas spp. Some of these genera were also found in indoor air in other studies $[13,14][20]$ $[34,35]$. Staphylococcus haemolyticus, micrococcus luteus, Rothia, and Bacillus subtilis are the successfully identified Gram-positive bacteria in this study. Staphylococci are generally found on the skin and mucous membranes of humans and animals. For genus Micrococcus, they are commonly found in the environment and as transient flora on the skin 
of humans and several other mammals. Therefore, it is not surprising that Staphylococcus and Micrococcus were identified to be present on both nurseries and DCCs.

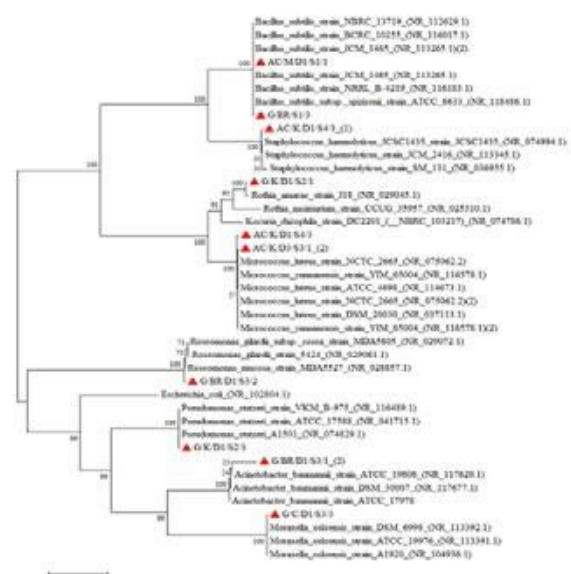

Figure 2: Neighbor-joining phylogenetic tree based on $16 \mathrm{~S}$ tRNA sequences derived from DNA extraction. The $16 \mathrm{~S}$ rDNA sequence of Escherichia coli was used as out group Scale bar

Based on Figure 2 S. haemolyticus was found and it has highly antibiotic resistant phenotype and its ability to form biofilms make it a difficult pathogen to treat [8]. As for micrococcus, it normally does not be considered as a pathogen but in individual with a compromised immune system like newborn infants, $M$. luteus can cause skin infections accompanied by severe itching [19],[30] reported that it is potential in colonizing the human mouth and upper respiratory tract.

Pathogenicity of Rothia spp. which also Gram-positive cocci are described in association with dental plaque and periodontal disease particularly children regardless its low virulence [11]. P. stutzeri is known as opportunistic pathogens [16] and has also been implicated in few infection cases. The predominance of a diverse array of Pseudomonas in the daycare appears to be quite consistent with the nature of the environment. The constant spillage of food and liquids, spread over every surface reachable by children, would make a perfect growth condition for this species [18]. Some potent bacteria species such as A. baumannii were also identified in this study. A. baumannii is a Gram-negative coccobacillus that can cause outbreaks of nosocomial infections because of its multidrugresistance patterns and its resistance to desiccation [23].

On the other hand, M.osloensis rarely infects humans, but it can sometimes be found in a variety of tissues, where it sometimes causes disease. Nonetheless, antibiotics are usually found to be effective against such infections [15]. Roseomonas spp.as described in [4] has been associated with human infection, normally as a secondary pathogen or opportunistic pathogen.

The Industry Code of Practice 2010 has recommended the acceptable limit for total fungal concentration which is $1000 \mathrm{CFU} / \mathrm{m} 3 . \mathrm{In}$ this study, the nurseries and day care centers in both locations recorded total fungal concentrations that were within the acceptable limits set by Industry Code of Practice 2010.

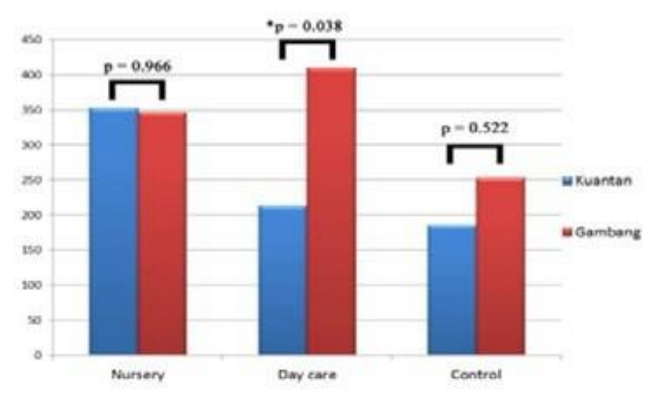

Figure 3: Comparison of airborne fungal concentration based on sampling stations. Note. $P$ value $<0.05 * *_{*}^{*}$ significant difference.

Figure 3 shows there was a significant difference between day care in ACK and ACG. Even though the number of occupants was about the same between these two rooms, in which the maximum occupants in ACK and ACG were 22 and 24 respectively, the concentration of airborne fungi doubled in ACG was recorded than that in ACK. This could be related to the building materials and moisture.

The source of humidity that may come from the nearby bathroom, doors, windows or air intakes possibly resulted in the absorption of moisture by the building materials such as wallboard, wallpaper and wood [33]. These circumstances will support fungal growth since indoor fungal concentration was found to have a positive correlation to relative humidity [26]. According to Lange, 2004 that the elimination of the source of indoor airborne pollutants is possible during the design phase of new building, but it is a hard task for an existing building [17]. Despite, both of this DCC building age was more than 10 years.

\subsection{Airborne fungi genera}

One of the fungi genera that was found in this study is Rhizopus spp., which is a fast growing colony that commonly found in the indoor environment. The distinctive and most important fungal genera found in ACG and ACK were Aspergillus spp. and Penicillium spp. which are relatively similar to the fungi collected from different indoor environment [9] such as campus [22], schools [22], house [2] and hospitals [25]. A study done in Singapore found that the most common fungi present in day care centers were Penicillium, Aspergillus, Geotrichum, and Cladosporium [35].

The spore formation is an utmost concern as babies and toddlers are at risk of developing asthma caused by the release of fungal spores into the air. Numerous evidences suggesting that asthma is associated with the presence of fungi and triggered by a large amount of fungal spores in the environment [10]. Thus, the occurrence of asthma symptoms is strongly correlated with an exposure to fungi in indoor environment [27].

4.0 CONCLUSION

IAQ assessment consists of three main parts which are biological, physical and chemical. In this study, the biological part was successfully covered which are CFU count and identification of microorganism species. Unfortunately, the physical and chemical part cannot be assess due to instrument limitation.

Two day care center that consist of babies and kindergarten room were surveyed and the concentration of microbial contaminant for both bacteria and fungi was fluctuated at both sites of ACK and ACG. The IAQ assessment have achieved its objectives in which the kind of nursery is proved to have a significant impact on the rate of indoor airborne bacteria because of differences in the ventilation system, proximity to the major road, and a number of occupants.

This study successfully identifies eight bacterial species from the sequencing of PCR products of selected bacterial cultures. Most of the species are pathogens or opportunistic pathogens. Moreover, some of the fungal genera present in this study were identified by morphological study.

\section{Acknowledgement}

The authors would like to thank the Ministry of Education and the International Islamic University Malaysia for supporting this research under RAGS 14-044-0107 Grant. REFERENCES

[1] Afroz, R., Hassan, M. N., \& Ibrahim, N. A. (2003). Review of air pollution and health impacts in Malaysia. Environmental Research, 92(2), 71-77. Doi: 10.1016/S0013-9351(02)00059-2

[2] Alwakeel, S. S. and Nasser, L. A. (2011). Indoor terrestrial fungi in household dust sample in Riyadh, Saudi Arabia.Microbiology Journal, 1 (1), $17-24$.

[3] An H.R.; Mainelis, G.; White, L.(2006). Development and Calibration of Real-Time PCR for Quantification of Airborne Microorganisms in Air Samples; Atmospheric Environment. 40 (40): 7924-7939

[4] Burge, P.S. (2004).Sick Building Syndrome. Occupational Environment Med. 61, 185-190.

[5] Centre, C. D. (2008). Early Childhood Care and Education Policy Implementation Review, 1-145

[7] Cionita, T., Jalaludin, J., Adam, N.M., \&Parlaungan J.(2014).Assessment of Children's Health and Indoor Air Contaminants of Day Care Centre in 
Industrial Area, 43(3), 81-88.

[8] De Allori, M. C. G., Jure, M. A., Romero, C., \& de Castillo, M. E. C. (2006). Antimicrobial Resistance and Production of Biofilms in Clinical Isolates of Coagulase-negative Staphylococcus strains. Biological \& Pharmaceutical Bulletin, 29(8), 1592-1596. http://doi.org/10.1248/bpb.29.1592.

[9] Degobbi, C., Lopes, F. D. T. Q. S., Carvalho-Oliveira, R., Munoz, J. E. and Saldiva, P. H. N (2011).Correlation of fungi and endotoxin with Pm2.5 and meteorological parameters in atmosphere of Sao Paulo, Brazil.Atmospheric Environment, 45, 2277-2283.

[10] Denning, D. W., O'Driscoll, B. R., Hogaboam, C. M., Bowyer, P. and Niven, R. M. (2006). The link between fungi a severe asthma: a summary of the evidence. Eur.Respir.J.27, 615/626.

[11] George M. Garrity (2005) Bergey’s Manual® of Systematic Bacteriology [12] Indoor Air Quality Management Group, the Government of Hong Kong Special Administrative Region (2003). Guidance Notes for the Management of Indoor Air Quality in Offices and Public Places, 1-110.

[13] Industrial Code of Practice on Indoor Air Quality. (2010). Department of Occupational Safety and Health.

[14] Jaffal, A. A., Banat, I. M., El Mogheth, A. A., Nsanze, H., Bener, A., \&Ameen,

A. S. (1997). Residential Indoor Airborne Microbial Populations in the United Arab Emirates. Environment International, 23, 529- 533. Doi: 10.1016/S0160-4120(97)00055-X.

[15] Kubota, H., Mitani, a., Niwano, Y., Takeuchi, K., Tanaka, a., Yamaguchi, N., Hitomi, J. (2012).Moraxella Species Are Primarily Responsible for Generating Malodor in Laundry. Applied and Environmental Microbiology, 78(9), 3317-3324.

[16] Lalucat J, Bennasar A, Bosch R, Garcia-Valdes E, Palleroni NJ: Biology of Pseudomonasstutzeri. MicrobiolMolBiol Rev 2006, 70(2):510-547.

[17] Lange, J.H., Thomulka, K.W., Mastrangelo, G., Fedeli, U., Quezada,N. V.(2004). Airborne mold concentrations during remediation of an apartment building.Bulletin of Environmental Contamination and Toxicology, 73, 487-489

[18] Lessie TG, Phibbs PV Jr. (1984). Alternative Pathways of Carbohydrate Utilization in pseudomonads. Annu Rev Microbiol 38:359-388.

[19] Madigan M; Martinko J (editors). (2005). Brock Biology of Microorganisms (11th ed.). Prentice Hall. ISBN 0-13-144329-1

[20] Mahdy, H.M., \& El-Sehrawi, M.H. (1997). Airborne Bacteria in the Atmosphere of ElTaif Region Saudi Arabia. Water, Air, and Soil Pollution, 98, 317-324

[21] MartinAraujo et al, (2014), Environment and Health in Children Day Care Centres, Revista Portugese

[22] Mat Hussin, N. H., Sann, L. M., Shamsudin, M. N. and Hashim, Z. (2011). Characterization of Bacteria and Fungi Bioaerosol in the Indoor Air of

Selected Primary Schools inMalaysia.Indoor and Built Environment, 20(6), 607-617.

[23] Monterrubio-Villar, J., Conza'lez-Velasco, C., Valdezate-Ramos, S., Co'rdoba-Lo 'pez, A., Villalo'n-Panzano, P., Sae'z-Nieto, J.A. (2009). Outbreak of Multi resistant Acinetobacter baumannii in a Polyvalent Intensive Care Unit: Clinical, Epidemiological Analysis and PFGE-Printing Evolution; Eur. J. Clin. Microbiol. Infect. 28, 1281-1284

[24] Pickering, L. K., Woodward, W. E., Dupont, L., \& Sullivan, P. (1984). Occurrence of Giardia

[25] Qudiesat, K., Abu-Elteen, K., Elkarmi, A., Hamad, M. and Abussaud, M. (2009). Assesssment of airborne pathogens in health care settings. African Journal of Microbiology, 3 (2), 66-76

[26] Rajasekar, A. and Balasubramanian, R. (2011).Assessment of airborne bacteria and fungi in food courts. Building and environment, 46(10), 20812087.

[27] Sahakian, N. M., Park, J. H. and Cox-Ganser, J. M (2008). Dampness and mold in the indoor environment: implications for asthma. Immunol Allergy Clin. North Am., 28, 485-505.

[28] Samson, R. A., Hoekstra, E. S., Frisvad,J.C. and Filternborg, O. (2000). IntroductiontoFood- and Airborne Fungi.Utrecht: CBS.

[29] Saravanan, N. P. 2004. Indoor Air Pollution: Danger at Home. Resonance. 6-11.

[30] Seifert H, Kaltheuner M, Perdreau-Remington F.(1995). Micrococcus luteus endocarditis: Case Report and Review of the Literature.

[31] US EPA. (1993). 'EPA's Approach \& Progress' in Targeting Indoor Air Pollution.

[32] WHO (2006).Air Quality Guidelines Global Update 2005.WHO Regional Office for Europe.

[33] Yang, C. S. (2004).Assessment of fungal contamination in buildings. Emlab P\&K, 110.

[34] Zhu, H., Phelan, P. E., Duane, T., Raupp, G. B., Fernando, H. J. S., \& Che, F. (2003). Experimental Study of Indoor and Outdoor Airborne Bacterial Concentrations in Tempe, Arizona, USA. Aerobiologia, 19, 201-
211. doi:10.1023/B:AER0.0000006571.23160.8a

[35] Zuraimi, M. S., Fang, L., Tan, T. K., Chew, F. T. and Tham, K.W. (2009). Airborne fungi in low and high allergic prevalence child care centers. Atmospheric Environment, 43, 2391-2400.

[36] Zuraimi, M.S., \& Tham, K.W. (2008). Indoor Air Quality and Its Determinants in Tropical Child Care Centers.Atmos Environ 42:2225-39 Copenhagen, Denamrk de Pneumologica 20(6):311-323 Lamblia in children in day carecentres. The Journal of Paediatrics, 104, 522-526 